3. Олексів Т. М. Науковопізнавальні стежки / Т. М. Олексів // Літопис природи природного заповідника «Горгани». - Т. 3. - Надвірна, 2002. - С. 3-20.

4. Приходько М. М. Фоновий моніторинг навколишнього природного середовища : монографія / М. М. Приходько, М. М. Приходько (старший), Я. О. Адаменко [та ін.]. - Івано-Франківськ : Фоліант, 2010. - 324 с.

5. Пушкар В. С. Доповнення до карабідофауни Природного заповідника «органи» / В. С. Пушкар // Наук. зап. Держ. природознавчого музею. - Львів, 2004. - № 19. - С. 185-186.

6. Ризун В. Б. Семейство Carabidae / В. Б. Ризун // Почвенные членистоногие Украинских Карпат. - Киев : Наук. думка, 1988. - С. 147-160.

7. Різун В. Б. Жуки-туруни (Coleoptera, Carabidae) природного заповідника «Горгани» / В. Б. Ризун // Наук. зап. Держ. природознавчого музею. - Львів, 2002. - o 17. - С. 63-80

8. Різун В. Б. Туруни Українських Карпат / В. Б. Ризун. - Львів, 2003. - 210 с.

9. Jaccard P. Distribution de la flore alpine dans le Bassin des Dranses et dans quelques regions voisines / P. Jaccard // Bull. Soc. Vaudoise sci. Natur. - 1901. - V. 37, Bd. 140. - S. 24-272.

10. Stocker G. Ein Modell der Dominanzstruktur und seine Anwendung. 1 Modelbildung. Modellrealisierung. Dominanzklassen / G. Stocker, A. Bergmann // Arch. Naturchutz. und Landschaftsforschung. - 1977. - Bd. 17, № 1. - S. 1-26.

11. Sustek Zbysek. Carabid communities (Coleoptera: Carabidae) in spruce forest in central Europe/ Zbysek Sustek // Museul Olteniei Craiova. Oltenia. Studii si comunicari. Stiintele Naturii. - T. 29. - № 2. - 2013. P. 140-154.

Слободян Елена. Сообщества жужелиц лесных экосистем природного заповедника «Горганы». Статья включает исследование экологического распределения жужелиц в разных лесных экосистемах заповедника. Определен видовой состав жужелиц на опытных участках. Проанализированы различия в составе доминантов, структуре доминирования и сезонной динамике сообществ жужелиц, что позволит разработать рекомендации для долговременного сохранения жужелиц в Карпатском регионе.

Ключевые слова: Carabidae, видовое разнообразие, природный заповедник «Горгани».

Slobodian Olena. Carabid Communities of Forest Ecosystem of the Gorgany Nature Reserve. The article includes a study of ecological distribution of ground beetles in the different forest ecosystem of the Reserve. It was identified species composition on the permanent plots. The differences in the composition of the dominants, the structure of domination and seasonal dynamics of ground beetles were analyzed. It will a base to develop action plan for long-term conservation of ground beetles in the Carpathian region.

Key words: Carabidae, species diversity, Gorgany Nature Reserve.

Стаття надійшла до редколегії 10.09.2016 р.

УДК 595.771: 614.449 .57

\author{
Катерина Сухомлін, \\ Валерій Капліч, \\ Олександр Зінченко
}

\title{
Сучасні хімічні методи контролю чисельності кровосисних мошок в умовах Українського Полісся
}

У роботі розглянуто ефективність використання сучасних хімічних препаратів із контролю чисельності імаго кровосисних мошок в умовах Українського Полісся. Доведено, що серед репелентів ефективними $\epsilon$ Advantix (крапельно на шкіру вздовж хребта тварини), репеленти виготовлені з місцевої лікарської сировини: багна звичайного (настій із гілок та листя) та пижма звичайного (настій із суцвіть); серед інсектицідів - неостомазан, перметрин, бутокс 200, ектосан ${ }^{\mathrm{TM}}$ і байтикол. Для створення інсектицидного бар'єру навколо ферм, літніх таборів та загонів для утримання тварин потрібно обробляти територію у радіусі до 200 м окурюванням димом (сира трава, шишки) та розприскуванням у радіусі 200 м ємульсій диброму й препарату Байгон 20 К. Е.

Ключові слова: контроль чисельності мошок, репеленти, інсектициди, Полісся.

(C) Сухомлін К., Капліч В., Зінченко О., 2016 
Постановка наукової проблеми та її значення. В умовах Українського Полісся з метою захисту від гнусу переглянуто кілька препаратів, що рекомендовані до використання Законом України «Про пестициди і агрохімікати» [1] й «Переліком пестицидів та агрохімікатів, дозволених до використання в Україні» [7]. Для обробітку тварин і дезінсекції тваринницьких приміщень рекомендовано використовувати Біорекс-ГX (Biorex-GH), Блотік (Blotic), Бутокс 210 (Butox), Декор-1 (Decor-1), Неостомозан (Neostomosan), Сумінак (Suminak), Ектомін (Ectomin), Ектосан ${ }^{\mathrm{TM}}$. Для обробітку приміщень та засобів догляду за тваринами - Байгон $1 \%$ дуст (Dust), Байгон 20 К. Е., Байтекс 40 \%, Діакап 300 CS (Diacap 300 CS), Сольфак $5 \%$ EW-050. Серед цих препаратів є як репеленти, що здатні відлякувати кровососів, так і інсектициди, які згубно діють на комах. При цьому враховано їх максимальну ефективність при низьких нормах витрат, токсичність та ін., що дало змогу обрати речовини, найбільш безпечні для навколишнього середовища й тварин.

Існує декілька способів контролю чисельності гнусу за допомогою хімічних засобів: деларвація біотопів із преімагінальними фазами кровосисних комах; дезінсекція тваринницьких приміщень; обробка тварин репелентами або інсектицидами та в окремих випадках - знищення дорослих комах у місцях випасу худоби.

Місця розвитку мошок переважно пов'язані з водоймами господарського призначення [9; 10], тому використання пестицидів тут заборонено.

Мета дослідження - оцінити ефективність застосування репелентів із місцевої лікарської сировини (пижма звичайного й багна звичайного) та інсектицидів нового покоління в умовах Українського Полісся.

Матеріал і методи дослідження. Для попередження залітання кровососів та тривалого захисту тварин від них навколо тваринницьких об'єктів створювали інсектицидний бар'єр. Ферми, літні табори, загони та навколишню територію в радіусі до 200 м обробляли $0,2 \%$-ними емульсіями пропоксура, 0,5 \%-ми - абата, байтекса, метатіона з нормою використання 30-50 мл/м² поверхні, яку потрібно обробити. Навколишню рослинність обробляли на висоту до двох метрів. Для прогону тварин на пасовище залишали широкий прохід. Для підтримання інсектицидної дії захисного бар'єру проводили повторний обробіток через 1-3 тижні, ураховуючи активність нападу гнусу. На обробленій території заборонено випасати худобу впродовж 7-20 діб, залежно від стійкості застосованого препарату та погодних умов.

Задля зниження економічних витрат і зменшення забруднення довкілля рекомендували щодня проводити одноразову обробку (обприскування) волосяного покриву тварин репелентами або інсектицидами в період масового нападу мошок (переважно I-II декади травня). У похмурі дні та перед дощем тварин не обприскували. Малооб'ємне аерозольне обприскування здійснювали вранці після доїння, груповим методом, проганяючи тварин через штанги горизонтальні розпилювальні (ШГР) із металевими жолобами для збору рідини, якою обприскували тварин (рис. 1). Обробляли всю поверхню шкіри тварин від голови до путових суглобів, уключаючи вим'я та зовнішні статеві органи самців. Неповна обробка тварин знижує ефективність їх захисту.

Для зменшення забруднення довкілля виготовлено металевий жолоб для збору рідини після обприскування (рис. 2). Застосування ШГР дає змогу скоротити удвічі час обробітку тварин і запобігає інтоксикації від випадкового отруєння. Щодо охорони природи використання репелентів має більші переваги, ніж застосування інсектицидів.

Дослідження проводили в КСП «Україна» с. Тростянець Ківерцівського району Волинської області (Акти впровадження від 15.05.2009).

Виклад основного матеріалу й обгрунтування отриманих результатів дослідження. Одномоментне знищення кровосисних двокрилих на обмежених площах здійснювали за допомогою аерозолів байгона, дихлофена на основі цифлутрину та тетраметрину. Однак в умовах Полісся вони були малоефективними. Звичайне окурювання димом давало кращий ефект. Короткочасного захисту тварин на відкритих ділянках у загонах досягали за допомогою обробки тваринницьких об'єктів та навколишньої території в радіусі до 100 м 0,2 \% емульсією диброму (диметилдибром-дихлоретилфосфат, ортодибром) iз розрахунку 150-200 л на 1-1,5 га. При цьому дрібнокрапельне розприскування проводили 3 гідропультів або дезустановок із розпилювачами та шлангами, які закріплені на довгих жердинах. 


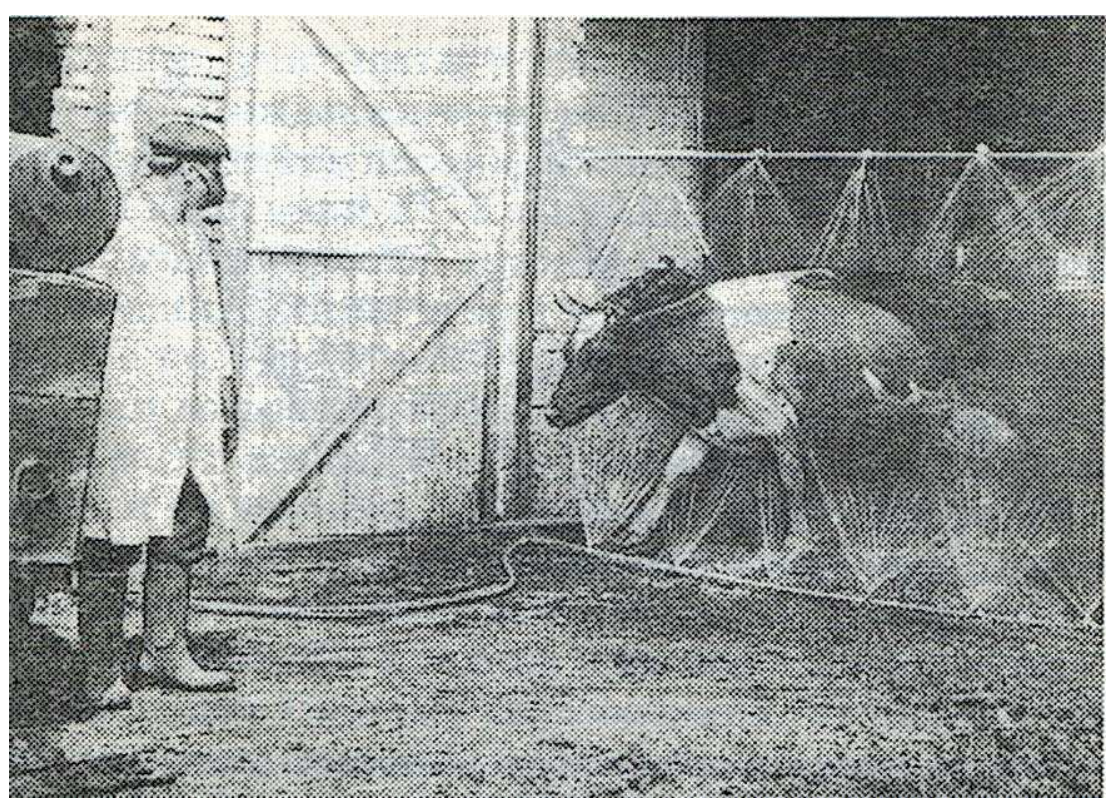

Рис. 1. Обробка тварин за допомогою штанг горизонтальних розпилюючих на територіі Жлобинського району Гомельської області в травні 1992 р. (за Капличем, Скуловием [2])

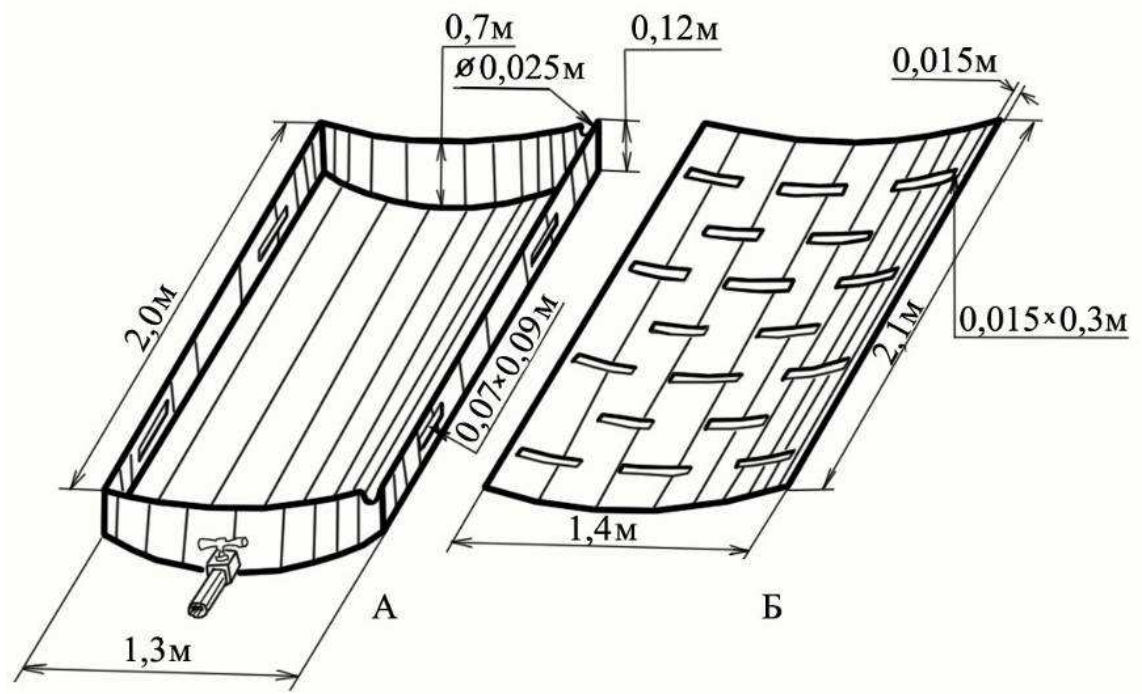

Рис. 2. Металевий жолоб для збору рідини після пристроїв для обприскування (за Капличем, Скуловцем [2])

Pепеленти. У якості репелентів працівники сільського господарства використовують бензимін (гексамід) і оксамат, які випускаються промисловістю у вигляді $60 \%$ емульгуючих концентратів. Обробку тварин проводять $3 \%$ емульсіями цих препаратів із розрахунку 1,5-2 л на дорослу тварину та 0,75-1 л для молодняку віком три місяці й більше методом дрібнокрапельного обприскування волосяного покриву.

Для досягнення більшої тривалості дії ми рекомендуємо використовувати концентровані $20 \%$ водні емульсії з розрахунку 100 мл на дорослу тварину та 50 мл для молодняку методом дрібнокрапельного обприскування або аерозольної обробки. Дійних корів обприскувати гексамідом у повному об'ємі заборонено [4; 5]. Рекомендуємо використовувати препарат нового покоління Advantix (Адвантикс) фірми «Вауег», який містить $10 \%$ імідаклоприду та $50 \%$ перметрину. Його наносять крапельно на шкіру вздовж хребта тварини. Репелентна дія триває 4-6 тижнів.

В умовах Білорусі (Брестська, Гомельська області) $[2 ; 3 ; 6]$ та України (Волинська область, Ківерцівський район, с. Тростянець КСП «Україна», Акти впровадження від 15.05.2009) успішно пройшли 
випробування репеленти, виготовлені з місцевої лікарської сировини - багна звичайного та пижма звичайного (табл. 1).

Таблиия 1

Результати впливу репелентів із місцевої сировини на активність імаго мошок (травень, 2009 р.)

\begin{tabular}{|c|c|c|c|c|c|}
\hline \multicolumn{2}{|c|}{ Показник } & Контроль & $\begin{array}{c}\text { Настій із багна } \\
\text { (обробка } 1 \text { раз } \\
\text { на добу) }\end{array}$ & $\begin{array}{c}\text { Настій із пижма } \\
\text { (обробка } 1 \text { раз } \\
\text { на добу) }\end{array}$ & $\begin{array}{c}\text { Настій із пижма } \\
\text { (обробка } 2 \text { рази } \\
\text { на добу) }\end{array}$ \\
\hline \multicolumn{2}{|c|}{$\begin{array}{c}\text { доза препарату } \\
\text { (мл/особину) }\end{array}$} & $\mathbf{0}$ & 50-100 & $300-500$ & $300-500$ \\
\hline \multicolumn{2}{|c|}{ кількість тварин } & 10 & 10 & 15 & 15 \\
\hline \multirow{9}{*}{ 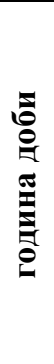 } & $5-6$ & 0 & 0 & 0 & 0 \\
\hline & $7-8$ & $8 \pm 0,2$ & 0 & 0 & 0 \\
\hline & $9-10$ & $22 \pm 0,4$ & 0 & $1,5 \pm 0,2$ & $1,2 \pm 0,1$ \\
\hline & $10-11$ & $15 \pm 0,3$ & 0 & 0 & $0,9 \pm 0,1$ \\
\hline & $12-13$ & 0 & 0 & 0 & 0 \\
\hline & 14-18 & $4 \pm 0,1$ & 0 & 0 & 0 \\
\hline & $19-20$ & $19 \pm 0,2$ & $2,9 \pm 0,1$ & $17 \pm 0,3$ & $1,5 \pm 0,1$ \\
\hline & $21-22$ & $8 \pm 0,2$ & 0 & $3 \pm 0,1$ & 0 \\
\hline & $23-24$ & 0 & 0 & 0 & 0 \\
\hline
\end{tabular}

Багно звичайне (Ledum polustris Linnaeus) - вічнозелений чагарник висотою до 120 см. Поширений на заболочених луках, у заболочених хвойних лісах. Для обробки тварин використовують настій із листя й молодих пагонів, які заготовляють у серпні-вересні. Настій із гілок та листя багна у співвідношенні $1: 20$ дозою 50-100 мл наносять один раз на день на поверхню тіла тварини. Результати досліджень довели, що в піддослідній групі тварин протягом 24 годин кровосисні мошки не сідали, однак активно літали навколо них, наближаючись до тіла на відстань 10-25 см. Багно звичайне має досить високі репелентні властивості.

Пижмо звичайне (Tanacetum vulgare Linnaeus) - багаторічна дикоросла трав'яниста рослина заввишки 120 см, досить поширена в лісових зонах. Збирають пижмо у липні-серпні. Лікарські властивості мають суцвіття, які використовують у медичній та ветеринарній практиці. Установлено інсектицидні властивості квітів і листя пижма для захисту від тарганів, клопів, мух [8; 11]. Суцвіття пижма звичайного застосовують у вигляді настою, відвару $(1: 10-20)$ або екстракту. Ці препарати наносять на тіло тварин уранці перед вигоном на пасовище з розрахунку 300-500 мл на тварину. Після обіду обробку тварин повторюють. Протягом 12 годин мошки на оброблених тварин не нападали. Отже, пижмо звичайне має репелентні властивості, але вони нижчі, ніж у багна звичайного (рис. 3).

Інсектициди. Серед інсектицидів найефективніші та найменш шкідливі для навколишнього середовища синтетичні піретроїди. Серед них добре зарекомендували себе неостомазан, перметрин, ектосан ${ }^{\mathrm{TM}}$ та байтикол $[4 ; 5 ; 6]$.

В умовах досліджуваного регіону неостомазан запобігає нападу мошок на тварин упродовж 13-14 годин, перметрин - 12-13 годин, байтикол - 8-9 годин. Інсектицидну обробку волосяного покриву тварин проводили $0,25 \%$ водною емульсією перметрину, неостомазану або $1 \%$ водною емульсією байтиколу методом малооб'ємних обприскувань із розрахунку 100 мл для дорослої тварини й 50 мл для молодняку.

Рекомендовано використовувати також Байгон (20\% пропоскур, виробництва Німеччини) у вигляді аерозолю або концентрату емульсії чи аерозоль ДЕТ (дельтаметрин 0,02\%, виробництва Донецького хімічного заводу, Україна). Щодо теплокровних тварин ці препарати виявляють середню токсичність. Вони чинять швидку інсектицидну дію, викликають різке зниження чисельності гнусу навколо тварин, яких обробляють. Використовували аерозолі або емульсії, здійснюючи дрібнокрапельне малооб'ємне обприскування волосяного покриву. Препарати захищали тварин від мошок упродовж 6-7 годин.

Високоефективним $є$ препарат Бутокс 200 (виробництва Голландії), який застосовують у вигляді 0,0025\% водної емульсії з нормою витрати 2-3 л на одну тварину, обприскування проводили один раз на 6-7 діб. 


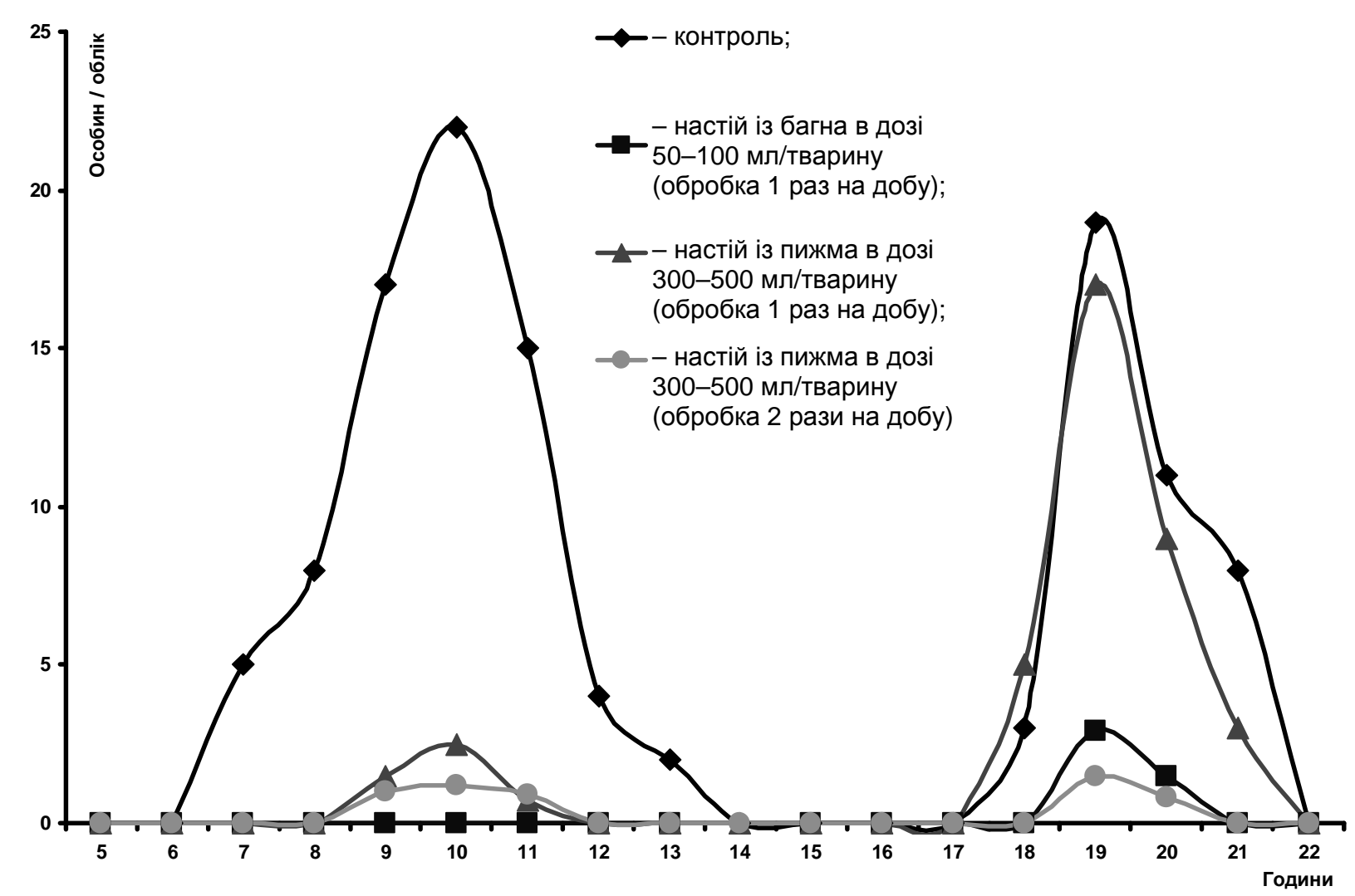

Рис. 3. Вплив настоянок із багна звичайного та пижма звичайного на активність нападу мошок (травень 2009 р.)

Українськими вченими (НВФ «Броварфарма») розроблено препарат Ектосан ${ }^{\mathrm{TM}}, 0,1 \%$ розчин використовують для захисту від гнусу один раз на добу в розрахунку $0,2-0,3$ л на одну тварину (велика рогата худоба, коні).

Ефективне створення інсектицидного бар'єру - обробка препаратами до 200 м території навколо ферм або місць випасання худоби. Для цього використовували Байгон 20 К. Е. (концентрат емульсії містить $20 \%$ пропоксура) у вигляді $0,5-1 \%$ емульсії в нормі $50 \mathrm{mл} / \mathrm{m}^{2}$ не частіше ніж один раз на місяць. Сольфак $5 \%$ EW-050 (EW-050) - водна емульсія, що містить $5 \%$ цифлутрин (піретроїд нового покоління). Застосовують 0,006-0,025 \% водні емульсії. Норма витрати препарату становить 50-100 мл/м². Повторну обробку проводять за ентомологічними показаннями.

Висновки й перспективи подальших досліджень. Сьогодні промисловість випускає значну кількість хімічних препаратів для контролю за чисельністю кровососів, тому основну увагу потрібно звернути на раціональне використання інсектицидів, які вже $\epsilon$. Для запобігання виникненню резистентності в комах до певного хімічного препарату потрібно чергувати їх застосування, тоді ефективність обробітку тварин буде вищою. Особливу увагу потрібно звернути на розробку нових інсектицидних препаратів із місцевої лікарської сировини, яка доступна всім господарствам і є екологічно безпечною.

\section{Джерела та література}

1. Закон України Про пестициди і агрохімікати № 86/95-ВР від 02.03.1995 / Верховна Рада України. Офіц. вид. - К. : Парлам. вид-во, 1995. - 91 с.

2. Каплич В. М. Кровососущие мошки (Diptera, Simuliidae) Беларуси / В. М. Каплич, М. В. Скуловец. Мн. : БГПУ им. М.Танка, 2000. - 365 с.

3. Каплич В. М. Меры борьбы с гнусом в Беларуси / В. М. Каплич, А. И. Ятусевич, М. В. Скуловец. Минск : Ураджай, 1994. - 80 с.

4. Павлов С. Д. Мероприятия против гнуса в животноводстве / С. Д. Павлов // Ветеринария. - К., 1981. № 6. - C. 15-17. 
5. Павлов С. Д. Пиретроиды против гнуса в животноводстве : материалы Всесоюз. конф. по паразитол. / С. Д. Павлов, Р. П. Павлова, Ю. И. Цапырин. - Ташкент, 1988. - С. 147.

6. Патогенные виды мошек (Diptera, Simuliidae) Полесья Беларуси : монография / [Ф. И. Василевич, В. М. Каплич, М. В. Скуловец и др.]. - М. : ФГОУ ВПО МГАВМиБ им. К. И. Скрябина, 2004. - 173 с.

7. Перелік пестицидів та агрохімікатів, дозволених до використання в Україні, затверджений Міністерством екології та природних ресурсів України від 29.12.2000: станом на 27 березня 2007 р. [Електронний pecypc]. - Режим доступу : http://www.uazakon.com/big/text1369/pg2.htm

8. Рекомендации по применению пижмы обыкновенной (Tanacetum vulgare L.) при паразитозах животных / [А. И. Ятусевич, Н. Ф. Карасев, М. В. Скуловец и др.]. - Витебск : ВОУС, 1995. - 9 с.

9. Сухомлін К. Б. Мошки (Diptera, Simuliidae) Волинського Полісся : монографія / К. Б. Сухомлін, О. П Зінченко. Луцьк : РВВ «Вежа» Волинського держ. ун-ту ім. Лесі Українки, 2007. - 308 с.

10. Фауна и экология мошек Полесья / В. М. Каплич, Е. Б. Сухомлин, 3. В. Усова, М. В. Скуловец. Минск : Ураджай, 1992. - 264 с.

11. Фитотерапия при паразитозах животных / [А. И. Ятусевич, Т. Г. Никулин, Н. Ф. Карасев и др.]. Витебск : [б. и.], 1993. - 43 с.

Сухомлин Екатерина, Каплич Валерий, Зинченко Александр. Современные химические методы контроля численности кровососущих мошек в условиях Украинского Полесья. В работе рассмотрена эффективность использования современных химических препаратов по контролю численности имаго кровососущих мошек в условиях Украинского Полесья. Доказано, что среди репеллентов эффективны Advantix (капельно на кожу вдоль позвоночника животного), репелленты изготовлены из местного лекарственного сырья: багульника болотного Ledum polustris (настой из ветвей и листьев) и пижмы обыкновенной Tanacetum vulgare (настой из соцветий) среди инсектицидов - неостомазан, перметрин, бутокс 200, ектосан ${ }^{\mathrm{TM}}$ и байтикол. Для создания инсектицидного барьера вокруг ферм, летних лагерей и загонов для содержания животных необходимо обрабатывать территорию в радиусе до 200 м путем окуривания дымом (сырая трава, шишки) и распыления в радиусе 200 м емульсий диброма и препарата Байгон 20 К. Э.

Ключевые слова: контроль численности мошек, репелленты, инсектициды, Полесье.

Sukhomlin Katheryna, Kaplich Valery, Zinchenko Olexander. Modern Chemical Methods to Control the Number of Blood-sucking Black Flies in the Ukrainian Polissya. In the paper has been considered the effectiveness of use the modern chemicals to control the number of adults biting black flies in the Ukrainian Polissya. It is proved that among repellents is effective Advantix (dripped to the skin along the animal's spine), repellents are made of local medicinal plant: Ledum polustris (infusion of branches and leaves) and Tanacetum vulgare (infusion of inflorescences) among insecticides - Neostomazan, Permethrin, Butoxy 200, Ektosan ${ }^{\mathrm{TM}}$ and Baytikol. To create an insecticide barrier around the farm, summer camps and paddocks for the animals, area must be treated within a radius of up to $200 \mathrm{~m}$ by smoke fumigation (wet grass, cones) and sprayed within 200 m emulsy by Dibrom and Baygon 20 K. E.

Key words: control the number of black flies, repellents, insecticides, Polesye.

Стаття надійшла до редколегії 22.09.2016 p.

Удк 595. 771(477)

\section{Олександр Левицький}

\section{Історія дослідження кровосисних комарів Українського Полісся}

Проаналізовано сучасний стан вивчення кровосисних комарів Українського Полісся. Установлено, що дослідження куліцидофауни регіону тривають понад 90 років. 3'ясовано, що значний внесок у вивчення Culicidae у 20-30-ті pp. ХХ ст. зробили О. О. Штакельберг та О. С. Мончадський, а починаючи з 50-х рр., - Г. К. Шевченко, А. В. Гуцевич, Н. С. Прудкіна, І. А Виноград, М. С. Дудкіна. Надзвичайно великий внесок у вивчення куліцид України зробив В. П. Шеремет, який визначив для Українського Полісся 41 вид із шести родів. На сучасному етапі дослідженням комарів регіону займаються Ю. В. Дубровський, Л. Д. Дубровська, В. Ф. Ясинська, 3. В. Корж, Н. П. Кілочицька.

Ключові слова: кровосисні комарі, видовий склад, фауна, Українське Полісся.

Постановка наукової проблеми та їі значення. Один з основним компонентів гнусу Українського Полісся - кровосисні комарі (Culicidae Diptera). Активність нападу гнусу на людину й тварин

(ㄷ Левицький О., 2016 